\title{
The Contribution of Business Management Trainings on Women Smallholder Farmers' Entrepreneurial Spirit in Siteki Area of Eswatini
}

\author{
Douglas Kibirige, Ajay S. Singh, Sotja G. Dlamini, Sebenele Mavuso \\ Department of Agricultural Economics \& Management, Faculty of Agriculture, University of \\ Eswatini, Luyengo M205, Eswatini. E-mail: kibirige@uniswa.sz
}

Received: Oct. 8, 2019

Accepted: Nov. 12, 2019 Published: Dec. 23, 2019

doi:10.5296/jas.v8i2.16120

URL: https://doi.org/10.5296/jas.v8i2.16120

\begin{abstract}
Women make essential contributions to the agricultural and rural economies in most developing countries including Eswatini yet they are the most visible face of poverty. As a strategy of empowering women to up-lift them from abject poverty, "Luhlelo Lolunotsisa Temabhizinisi" (LULOTE) has developed business management training programs for rural women smallholder farmers to enhance their entrepreneurship spirit and skills. The LULOTE in English can be interpreted as a program that helps businesses to advance/prosper. It is a Non-Governmental Organization was established in 1986 in Eswatini to promote entrepreneurial culture and inspire entrepreneurs. This paper ought to find out the contributions of business management trainings on the level of entrepreneurial spirit and skills of women smallholder farmers as its main objective. Data was collected through the use of questionnaires and personal interviews with a sample size of 120 farmers. Descriptive statistics and the Ordinary Least Square (OLS) multiple regression models were used as methods of analysis. The results of this study indicate that most farmers interviewed were aged above 49 years, married (40\%), and primary school dropout (mean of 6 years in school), spent an average of 10 years in farming and at least $50 \%$ on average indicated that farming was their main occupation. Results further revealed that the trained women by LULOTE had a higher entrepreneurial spirit than the non-trained women scoring an average index of 3.45 and 2.77, respectively. The LULOTE trained women also were rated higher with a 3.50 score compared to the non-trained rated at 3.01 scores. The determinants of level of entrepreneurial spirit among sampled women included age of respondent, level of education, farming as major occupation, and incomes from remittances. Determinants of level of entrepreneurial skills among sampled women included, farming income, off-farm income and previous job of the respondent. Based on the independent T-test results, there was a significant difference in the statements mean scores related to the level of farmers' entrepreneurial spirit \& Skills
\end{abstract}


between LULOTE members and non-LULOTE members at $1 \%$ and $5 \%$ level. Therefore, the research concludes that LULOTE trainings greatly contributed to improving the entrepreneurial spirit and skills of the women. Since there is an observable positive result of training women, all stakeholders including government, private sector, Non-Governmental Organizations (NGOs), among others should increase on the training programs for all farming age groups including the youth.

Keywords: women farmers, entrepreneurship spirit, entrepreneurship skills, business management training

\section{Introduction}

In the developing world globally, strategies aimed at promoting agricultural commercialization are envisaged as engines for economic growth important to reduce the gap of income inequality, poverty alleviation, improve on food security, and the general livelihoods of especially rural communities (Cheryl, 2011). This anticipated agricultural growth for rural development has hardly taken off especially in the Sub-Saharan Africa, partially due to the slow pace of achieving gender equality, leading to women denial for crucial agricultural productive resources (Cheryl, 2011). Women contributed $60 \%$ to $70 \%$ of rural agricultural labor compared with their male counterparts (Agarwal, 2011 and Mucavele, 2013). Women make essential contributions to the agricultural and rural economies in all developing countries. Given their key role to economic growth, women's economic empowerment is recognized as one means to reduce poverty, food security, equal income distribution and overall role rural livelihoods (Mucavele, 2013).

The women face challenges arising from indirect gender associations that identify entrepreneurship with men and masculinity. Gender conflicts at the organization level are observed where men oppose women males being subordinates in the business partnership. There is need for women to stand the pressure of adjusting to their gender identity in the surrounding community where they stay or work (Tarmizi, et al., 2016). Aslam, et al. (2013) spells out the factor that hinder growth of women entrepreneurs including securing finances for business, lack of entrepreneurial and management competence and exposure, problems in finding markets and distribution networks; absence of technological know-how; lack of support from family, society and government is a problem and poor education and training on know-how to manage the business, conducting feasibility study, profitability analysis, quality control, marketing and financial and technical management. In addition, promotion and marketing of products and services is a problem for women entrepreneurs. Women entrepreneurs also face social difficulties, like as lack of the family support, gender inequality, lack of entrepreneurial education and skills. All these problems were found to have a negative impact on the working efficiency of the women entrepreneurs, thus affecting their entrepreneurial spirit/drive. Farmer's entrepreneurial spirit can be manifested in her/his hope, resilience, optimism and self-efficacy. Holden (2019) relates the positive psychological capital concepts to entrepreneurial spirit indicating that a successful entrepreneur needs self-confidence, confronting uncertainty, hope and perseverance.

Women exclusion from commercial agriculture and agro-entrepreneurship stems from the 
traditional cultural norms. The women were considered as home makers while they are the primary labor force on small farms mainly producing for home consumption (Cheryl, 2011 and Agarwal, 2011). The girl child had limited opportunity to attend formal school resulting in a higher number of women being illiterate. This has exposed them to relatively higher vulnerable to high poverty levels, food insecurity and a miserable livelihood (Vulnerability Assessment Committee (VAC), 2019). Among strategies of empowering women includes drafting and enacting laws that allow women access to agricultural resources like land. In addition, women are empowered through trainings important for sustainable agribusiness in increasing women income earnings and the general rural economic growth (Mucavele, 2013).

Eswatini is among countries that are taking the right path of empowering women for increased production in agriculture and rural economic development notwithstanding the enormous challenges they face including convergence of logistical, cultural, and economic factors (FANPARN, n.d). In Africa, less than $10 \%$ of women farmers access agricultural extension services (Okello et al., n.d.). A study by FAO found that if women received the same education and similar inputs and assistance as men, overall farm yields could rise by as much as 22 percent (FANPARN). According to Masuku (2012), the livelihood in the rural areas of Swaziland are driven by women especially those participating along the agribusiness value chain from agricultural production to the final consumer. To cultivate and catalyze women agro-entrepreneurial skills and spirits respectively, the government of Swaziland organizes competitions that lead to warding the women farmer of the year (Masuku, 2012).

In addition government through its parastatals, NGOs, CBO and concerned stakeholders have training programs that are gender responsive. Among initiatives include the Food and Agricultural Organization (FAO-UN) in partnership Luhlelo Lolunotsisa Temabhizinisi (LULOTE) who introduced the project of sweet potato value chain meant to empower rural women and introduce them to commercial farming in 2018. The partnership between FAO and LULOTE included market linkage for the farmers and conducting business management training to the women in the rural areas of the Kingdom of Eswatini. These trainings were meant to enlighten the rural women on the different business management and entrepreneurial concepts to help them run their businesses and develop improved entrepreneurial spirit and skills. Smith (2013) defines entrepreneurial spirit as a mentality, assertiveness and approach to thinking actively pursues change without waiting to adapt to change.

LULOTE-BMEP is a non- profit organization based in Manzini in the Kingdom of Eswatini. It was established in 1986 for the promotion of entrepreneurial culture to both existing and aspiring entrepreneurs of the kingdom. Among other services, LULOTE provide training and business consultancy services like business planning and cash flows to existing and aspiring entrepreneurs to capacitate them for business improvement. LULOTE has expertise from the International Labour Organization (ILO) accredited courses that can help empower local communities in areas such as; generating business ideas, starting new businesses or improving existing ones, developing business plans, market research, client profiling financial statements and cooperative management. 


\section{Ml Macrothink}

Currently, there is limited information related to evaluation of the contribution of this FAO and LULOTE partnership on improving women's entrepreneurial spirit and skills in Eswatini. The main objective of the study was to find out the contributions of business management training on the entrepreneurial spirit and skills of women smallholder farmers and this paper also includes a comparison of the socio-economic characteristics of women farmers trained and those not trained by LULOTE. Estimate and compare the level of entrepreneurial spirit and skills between trained women farmers and those who were not trained; and identify the determinants of women entrepreneurial spirit and skills.

\section{Methodology}

The study was conducted at Siteki in the Lubombo region of the Kingdom of Eswatini which is located in the east of the country. Lubombo has an area of 5849.11 square kilometers and had a population of 207731 in the year 2007. This region borders all the other regions: Hhohho to the north, Manzini to the west, and Shiselweni to the south. Lubombo region receives an average rainfall of $768 \mathrm{~mm}$ in a year, has a warm and temperate climate with an annual average temperature of 21.1. This area was ideal for the study because the target population was among the selected participants in the FAO-LULOTE sweet potato project.

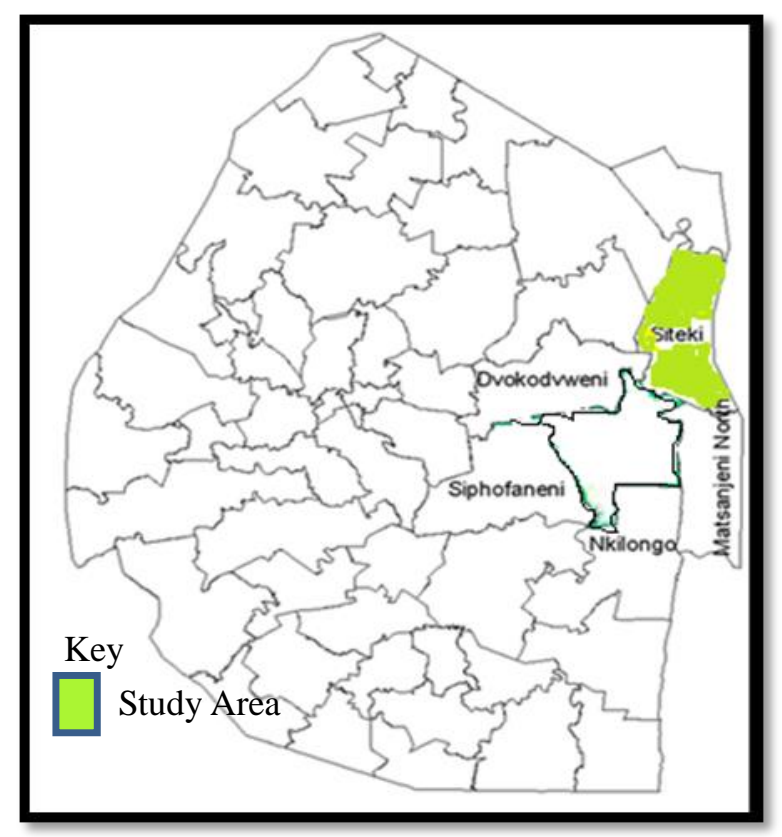

Figure 1. Map of Eswatini Showing Siteki Area

The estimated population size of this study was 165 individual women farmers, members of farmer groups. In the study area, four women farmer groups were trained by LULOTE and 7 groups were not trained by the same organization. Each group is composite of about 15 members. The study used all the four groups trained by LULOTE in the area composed of 60 individual members. For comparison purposes, another 60 individual members were selected from four groups not trained by LULOTE. The seven groups of women farmers not trained by LULOTE were arranged according to their dates of formation, starting with the one that was formed earlier to the one that was formed recently. Four groups were selected using 
systematic random sampling. Therefore, this study used a sample of 60 respondents trained by LULOTE and 60 respondents who never received any training from LULOTE making an overall total sample size of 120 women farmers. Information was collected from selected respondents by using self-structured questionnaire. In-person, face to face interviews was conducted to gain trust worthy information and cooperation from the respondents. Self-structured questionnaires to collect primary data were used as a key instrument for both qualitative and quantitative information. The questionnaire was pre-tested for data reliability and validity. Both qualitative and quantitative unbiased information was captured by the researcher.

The captured data was entered in computer using Microsoft Office Excel and analyzed according to each specific objective of the study with appropriate software. To estimate and compare the level of entrepreneurship skills and spirit between the trained women farmers and those who are not trained, the study used a Likert scale and independent t-test. Descriptive statistics which included graphs and frequency tables were used to compare the socio-economic factors of trained women farmers and those who were not trained. Multiple linear regression was used to determine the relationship between the socio-economic characteristics of the women farmers and the level of entrepreneurship skills and spirit. The socioeconomic characteristics, education and experience were measured according to the number of years. For education the study used the number of years spent by the respondents in school and for experience the study used the number of years the respondent has spent in farming.

The study adopted a Likert scale developed by Kibirige (2013) to estimate the level of entrepreneurial spirit, and the researchers used the training manual of LULOTE to develop the Likert scale related to entrepreneurial skills gained by the farmers. Positive statements related to entrepreneurial spirit were developed depicting the characteristics of an entrepreneurial including goal-oriented, persistent hardworking and energetic, willing to take initiative and innovative spirit, and have a strong sense of commitment; sense opportunities and develop new technologies, new markets, and set-up new organizations to satisfy a given need. The Likert scale was rated as 1-strongly disagree, 2-disagree, 3-agree, 4-strongly agree. Thus a mean score of less than 3 indicates low entrepreneurial spirit and above 3 indicates a higher entrepreneurial spirit of the smallholder women farmers.

The multiple linear regression model in this study incorporated the total average scores measured using the Likert scale. The linear model is estimated as:

$$
\Theta=\beta X+\mathrm{e} \ldots \ldots \ldots
$$

Empirically this model can be expressed as:

$$
\begin{array}{r}
\Theta=\beta_{0}+\beta_{1} \text { AGE }+\beta_{2} \text { MARITAL }+\beta_{3} \text { EDUC }+\beta_{4} \text { MJOCUP }+\beta_{5} \text { PJOB }+\beta_{6} \text { FARMINCOME }+ \\
\beta_{7} \text { OFFINCOME }+\beta_{8} \text { REMITTANCES }+\mathrm{e} \ldots \ldots \ldots \ldots \ldots \ldots \ldots \ldots \ldots \ldots \ldots \ldots \ldots \ldots \ldots \ldots \ldots \ldots \ldots \ldots \ldots \ldots \ldots \ldots \ldots \ldots \ldots \ldots
\end{array}
$$

Where $\Theta$ is the dependent variables measured as the average mean scores of the farmers' entrepreneurial spirit and skills statements, $\beta_{0}$ to $\beta_{8}$ are coefficients to be estimated, AGE $=$ Age of respondent (years); MARITAL $=$ Marital status of respondent $(1=$ married, 


\section{Macrothink}

0=otherwise); EDUC =Level of education of respondent (years in School); MJOCUP =Major employment of respondent ( $1=$ farming, $0=$ otherwise); $\mathrm{PJOB}=$ Previous job of respondent (1=Formal, $0=$ Otherwise); FARMINCOME =Respondent's farm income (Emalangeni); OFFINCOME=Respondent's income off-farming (Emalangeni); REMITTANCES= Respondent's income from remittances Emalangeni) and $\mathrm{e}=$ the error term.

\section{Results and Discussions}

\section{Respondents' socio-economic characteristics}

Age of Respondents: Table 1 shows the socio-economic characteristics of the women smallholder farmers. Most of the farmers both trained and those who are not trained are between the ages of 40-49 which makes up $41.7 \%$ for trained farmers and $40 \%$ for those who were not trained. Women farmers between the ages of 30-39 make up 16.7\% of the trained farmers and $8.3 \%$ for those who were not trained. The mean age for the women farmers who were trained was 49 years and for those who were not trained was 50 years. This showed that the farmers who were trained are younger in age compared to those who were not trained.

Table 1. Distribution of age of respondents

\begin{tabular}{lllll}
\hline & $\begin{array}{l}\text { Farmers } \\
\text { Trained) }\end{array}$ & & Farmers (Not \\
\hline Variables & Frequency & Percentage & Frequency & Percentage \\
$\begin{array}{l}\text { Age } \\
\text { (Yrs.) }\end{array}$ & & & & \\
$30-39$ & 10 & 16.7 & 05 & 08.3 \\
$40-49$ & 25 & 41.7 & 24 & 40.0 \\
$50-59$ & 13 & 21.7 & 20 & 33.3 \\
$60-69$ & 10 & 16.7 & 10 & 16.7 \\
$70-79$ & 02 & 03.3 & 01 & 01.7 \\
\hline
\end{tabular}

Source, survey data 2019

Marital status: The results on the marital status of respondents from Table 2 showed that a majority of the women farmers were married. For the trained farmers $8.3 \%$ were single, $68.3 \%$ were married, $5 \%$ were divorced and $18.3 \%$ were widowed. For the women farmers who were not trained, $5 \%$ were single, $75 \%$ were married, $10 \%$ were divorced and $10 \%$ were widowed. The results indicate that there are more widowed women who were participating in the LULOTE trainings compared to those not trained by the same organization. This may be 
due to the organization's intention to support mostly groups with more number of vulnerable members.

Table 2. Distribution of Marital Status of respondents

\begin{tabular}{lccccccc}
\hline $\begin{array}{l}\text { Marital status of } \\
\text { respondent }\end{array}$ & \multicolumn{2}{c}{ Trained } & \multicolumn{2}{c}{ Not Trained } & \multicolumn{2}{c}{ Total } & \multirow{2}{*}{ Chi-Square value } \\
\cline { 2 - 6 } & Freq. & $\%$ & Freq. & $\%$ & Freq. $\%$ & \\
\hline Single & 05 & 08 & 03 & 05 & 08 & 07 & 3.157 \\
Married & 41 & 68 & 45 & 75 & 86 & 72 \\
Divorced & 03 & 05 & 06 & 10 & 09 & 08 \\
Widowed & 11 & 18 & 06 & 10 & 17 & 14 \\
Total & 60 & & 60 & & 120 & \\
\hline
\end{tabular}

Source, survey data 2019

Farming experience: The results also show that $93.3 \%$ of the women farmers who were trained had a farming experience that ranged from 1-10 years and $6.7 \%$ had a farming experience that ranged from 11-20 years. For the farmers who were not trained, $71.7 \%$ had a farming experience of 1-10 years, 20\% had a farming experience of $11-20$ years, $3.3 \%$ had a farming experience of 21-30 years, and 5\% had a farming experience of 31-40 years. The average farming experience for the trained women farmers was six yes which was less as compared to the average farming experience of ten years of the farmers who were not trained. See Table 3.

Table 3. Farming experience of respondents

\begin{tabular}{llcll}
\hline & \multicolumn{1}{c}{ Farmers (Trained) } & \multicolumn{2}{c}{ Farmers (Not Trained) } \\
\hline $\begin{array}{l}\text { Farming } \\
\text { Experience } \\
\text { (years) }\end{array}$ & Frequency & Percentage & Frequency & Percentage \\
\hline $1-10$ & 56 & & & \\
$11-20$ & 04 & 93.3 & 43 & 71.7 \\
$21-30$ & 00 & 06.7 & 12 & 20.0 \\
$31-40$ & 00 & 00.0 & 02 & 03.3 \\
\hline
\end{tabular}

Source, survey data 2019

Level of education: The results in Table 4 show that $23.3 \%$ of trained farmers who were interviewed never attended school, $18.3 \%$ attained primary school education, $56.7 \%$ had 
secondary education, and $1.7 \%$ had tertiary education. None of the farmers who were not trained had tertiary education, $25 \%$ of the farmers who were not trained never attended school, $20 \%$ attended up to primary level, and 55\% attended up to secondary level. These results match the results of a study by (Gbadeyan, 2017) which states that education may serve as a significant factor for starting a business and can positively impact the success of the small business

Table 4. Distribution of level of education of respondents

\begin{tabular}{lllll}
\hline & \multicolumn{2}{l}{ Farmers (Trained) } & \multicolumn{2}{l}{ Farmers (Not Trained) } \\
\hline Level of Education & Frequency & Percentage & Frequency & Percentage \\
\hline Never attended school & 14 & 23.3 & 15 & 25 \\
Primary & 11 & 18.3 & 12 & 20 \\
Secondary & 34 & 56.7 & 33 & 55 \\
Tertiary & 01 & 01.7 & 00 & 00 \\
\hline
\end{tabular}

Source, survey data 2019

Major source of employment for respondents: The findings of this study show that the majority of respondents rely on farming as their major source of employment. About $91.7 \%$ of the trained farmers rely on farming as their major employment and $83.3 \%$ of those who were not trained also rely on farming as their major source of employment. More women trained by LULOTE relied on farming as their major occupation compared to non-LULOTE members. This could be one of the selection criteria of LULOTE to target women dedicated to farming to realize more impact of their efforts and ensure efficient utilization of the training resources.

Table 5. Distribution of major employment of respondents

\begin{tabular}{lccccccc}
\hline $\begin{array}{l}\text { Major } \\
\text { employment }\end{array}$ & \multicolumn{2}{c}{ Trained } & \multicolumn{2}{c}{ Not Trained } & \multicolumn{2}{c}{ Total } & \multicolumn{2}{c}{$\begin{array}{c}\text { Chi- } \\
\text { respondent }\end{array}$} & Freq. & $\%$ & Freq. & $\%$ & Freq. & $\%$ & Square Value \\
\hline Farming & 55 & 92 & 50 & 83 & 105 & 88 & 2.571 \\
Casual worker & 04 & 07 & 08 & 13 & 12 & 10 & \\
Private company & 00 & 00 & 01 & 02 & 01 & 01 & \\
NGO/Cooperative & 01 & 02 & 01 & 02 & 02 & 02 & \\
\hline
\end{tabular}

Experience on previous business: The results of the study presented on Table 6 show that the average years spent by the trained farmers on their previous business was about three years while the average years spent by the farmers who were not train on their previous businesses was about only a year. The smallholder women farmers who spent more years on previous businesses will therefore have an increased entrepreneurial spirit and skill due to the experience and expertise as compared to the farmers who spent much less time on businesses before and hence they do not have much experience and expertise of running a business or 
being an entrepreneur for that matter. A study by (Aghajani, 2012) states that more experience in running a business increases the level of entrepreneurial spirit and expertise of an entrepreneur, therefore the results from the two studies match.

Income from farming: The results presented on the Table 6 show that there is a significant difference between the farming income of the trained farmers and the farming income of the farmers who were not trained. The mean income of the trained farmers was E1061 and it was greater than that of the farmers who were not trained with their mean income being E588. The difference between the income of the farmers who were trained and the income of the farmers who were not trained is probably as a result of the difference in the level of entrepreneurial spirit and skills. Farmers with a higher level of entrepreneurial spirit and skills perform better on their business as compared to the farmers who have low entrepreneurial spirit and skills.

Off-farming income: The results in Table 6 show that the average income trained farmers generated from off-farming activities was about E662 and that of farmers who were not trained was E739. A majority of the trained farmers revealed that they focus most of their time and energy on farming activities and they hardly have other activities on the side to generate income. They also added that even if they have the off-farming activities, they usually do not succeed unless they hire someone which they do not afford to do.

Table 6. Means for socio-economic factors of respondents

\begin{tabular}{|c|c|c|c|c|c|}
\hline & $\begin{array}{l}\text { Whether received any form } \\
\text { of business training }\end{array}$ & $\mathbf{N}$ & Mean & Std. Deviation & t-value \\
\hline \multirow{2}{*}{ Age of respondent } & Yes & 60 & 49.4833 & 9.88492 & -0.451 \\
\hline & No & 60 & 50.2333 & 8.26134 & \\
\hline \multirow{2}{*}{$\begin{array}{l}\text { Number of years spent by } \\
\text { respondent in school }\end{array}$} & Yes & 60 & 7.3500 & 4.63526 & 0.734 \\
\hline & No & 60 & 6.7333 & 4.57283 & \\
\hline \multirow{2}{*}{$\begin{array}{l}\text { Number of years spent by } \\
\text { respondent in farming }\end{array}$} & Yes & 60 & 6.6333 & 3.60774 & -3.288 \\
\hline & No & 60 & 10.3667 & 8.02109 & \\
\hline \multirow{2}{*}{ Respondent's income } & Yes & 60 & 3990.8333 & 1061.82812 & $19.210 * * *$ \\
\hline & No & 60 & 979.7500 & 588.78460 & \\
\hline \multirow{2}{*}{$\begin{array}{l}\text { Respondent's } \\
\text { off-farming }\end{array}$} & Yes & 60 & 1716.5833 & 662.16164 & $2.111 * *$ \\
\hline & No & 60 & 1446.1000 & 739.12091 & \\
\hline \multirow{2}{*}{$\begin{array}{l}\text { Respondent's income from } \\
\text { remittances }\end{array}$} & Yes & 60 & 603.2000 & 348.50600 & $2.417 * *$ \\
\hline & No & 60 & 463.8333 & 279.25501 & \\
\hline \multirow{2}{*}{$\begin{array}{lrr}\text { Number } & \text { of } & \text { years } \\
\text { respondent } & \text { ran } & \text { previous } \\
\text { business } & & \end{array}$} & Yes & 60 & 3.0333 & 4.39170 & $2.861 * *$ \\
\hline & No & 60 & 1.2500 & 2.00529 & \\
\hline
\end{tabular}

Where $* *, * * *=$ significance level of $5 \%, 1 \%$, respectively. 


\section{Macrothink}

Journal of Agricultural Studies

ISSN 2166-0379

2020, Vol. 8, No. 2

Income from remittances: The results of the study that are presented in Table 6 show that the average income trained farmers receive from remittances were about E348 and that of the farmers who were not trained was about E279.

\section{Estimating the Level of Entrepreneurial Spirit among Women}

Using the Likert scale that was rated as follows, 1-strongly disagree, 2-disagree, 3-agree, 4-strongly agree the mean entrepreneurial spirit of the smallholder women farmers was measured. Table 7 shows the mean entrepreneurial spirit of the smallholder women farmers in relation to whether they have received business management training or not. The results show that trained smallholder women farmers have a positive attitude towards doing business since their mean entrepreneurial spirit was 3.45 greater than that of the smallholder farmers who were not trained with their mean entrepreneurial spirit being 2.77. Most of the t-values in Table 7 are significant at $1 \%$ level which shows that there is a significant difference in the scores of level of entrepreneurship spirit component reflected in each of the statements presented in the Likert scale between the trained smallholder women farmers and those who were not trained. 
Table 7. Level of entrepreneurial spirit of respondents

\begin{tabular}{|c|c|c|c|c|c|c|c|}
\hline \multirow[b]{2}{*}{ Entrepreneurial spirit } & \multicolumn{2}{|c|}{$\begin{array}{l}\text { Women Farmers } \\
\text { (Trained) }\end{array}$} & \multicolumn{2}{|c|}{$\begin{array}{l}\text { Women } \\
\text { Farmers } \\
\text { (Not trained) }\end{array}$} & \multicolumn{2}{|c|}{ Overall sample } & \multirow[t]{2}{*}{ t-value } \\
\hline & Mean & SD & Mean & SD & Mean & SD & \\
\hline 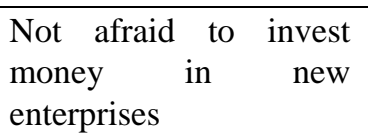 & 3.617 & 0.490 & 3.333 & 0.510 & 3.475 & 0.500 & $3.103 * * *$ \\
\hline $\begin{array}{l}\text { Irrespective of the } \\
\text { challenges I continue } \\
\text { trying until the solution } \\
\text { is got }\end{array}$ & 3.550 & 0.502 & 2.900 & 0.512 & 3.225 & 0.506 & $7.032 * * *$ \\
\hline $\begin{array}{l}\text { If there is a change in } \\
\text { supply and demand you } \\
\text { take action faster before } \\
\text { government does }\end{array}$ & 3.317 & 0.624 & 1.800 & 0.576 & 2.558 & 0.600 & $13.828 * * *$ \\
\hline $\begin{array}{l}\text { Take action always on } \\
\text { the basis of what you } \\
\text { perceive profitable }\end{array}$ & 3.500 & 0.504 & 2.983 & 0.390 & 3.242 & 0.447 & $6.277 * * *$ \\
\hline $\begin{array}{lr}\text { I do not } & \text { wait for } \\
\text { subsidies } & \text { before } \\
\text { applying } & \text { new } \\
\text { technology } & \end{array}$ & 3.133 & 0.536 & 1.783 & 0.640 & 2.458 & 0.588 & $12.526 * * *$ \\
\hline $\begin{array}{l}\text { You take your own } \\
\text { judgment about new } \\
\text { technology before } \\
\text { consulting friends }\end{array}$ & 3.567 & 0.500 & 3.017 & 0.344 & 3.292 & 0.422 & $7.022 * * *$ \\
\hline $\begin{array}{l}\text { Not afraid to be } \\
\text { different when you try a } \\
\text { new technology in your } \\
\text { farm }\end{array}$ & 3.433 & 0.563 & 2.417 & 0.591 & 2.925 & 0.577 & $9.647 * * *$ \\
\hline $\begin{array}{l}\text { Spend more time in new } \\
\text { technologies where you } \\
\text { anticipate profits }\end{array}$ & 3.400 & 0.527 & 2.100 & 0.681 & 2.75 & 0.604 & $11.687 * * *$ \\
\hline $\begin{array}{l}\text { You are not afraid of } \\
\text { investing more money } \\
\text { in new technologies }\end{array}$ & 3.467 & 0.536 & 2.217 & 0.783 & 2.812 & 0.659 & $10.205^{* * *}$ \\
\hline $\begin{array}{l}\text { Quickly adapt to change } \\
\text { in supply, } \\
\text { demand and consumer } \\
\text { preferences }\end{array}$ & 3.233 & 0.533 & 2.650 & 0.515 & 2.942 & 0.524 & $6.099 * * *$ \\
\hline $\begin{array}{l}\text { Risks of new } \\
\text { technologies isn't your } \\
\text { first priority }\end{array}$ & 3.157 & 0.537 & 3.033 & 0.410 & 3.095 & 0.493 & $5.348 * * *$ \\
\hline $\begin{array}{l}\text { Willing to pay for any } \\
\text { farm related trainings }\end{array}$ & 3.500 & 0.504 & 3.150 & 0.577 & 3.325 & 0.541 & $3.538 * * *$ \\
\hline $\begin{array}{l}\text { Will to source for } \\
\text { information wherever } \\
\text { possible at a cost }\end{array}$ & 3.317 & 0.469 & 3.250 & 0.571 & 3.283 & 0.520 & 0.699 \\
\hline $\begin{array}{l}\text { Persist in spite of any } \\
\text { difficulties }\end{array}$ & 3.767 & 0.427 & 3.333 & 0.475 & 3.55 & 0.451 & $5.256 * * *$ \\
\hline $\begin{array}{l}\text { Willing to expand the } \\
\text { business }\end{array}$ & 3.883 & 0.324 & 3.633 & 0.520 & 3.758 & 0.422 & $3.163 * * *$ \\
\hline Total average scores & 3.4462 & 0.505 & 2.773 & 0.540 & 3.11 & 0.524 & \\
\hline
\end{tabular}


Where $* * *=$ significance level of $5 \%, 1 \%$, respectively

\section{Estimating the Level of Entrepreneurial Skills among Women}

Using the Likert scale that was rated as follows, 1-strongly disagree, 2-disagree, 3-agree, 4-strongly agree the mean entrepreneurial skills of the smallholder women farmers was measured. Table 8 shows the mean entrepreneurial skills of the smallholder women farmers in relation to whether they have received business management training or not. The results show that trained smallholder women farmers have more business management skills since their mean for entrepreneurial skills was 3.50 greater than that of the smallholder farmers who were not trained with their mean for entrepreneurial skills being 3.01. Most of the t-values in Table 8 are significant at $1 \%$ level which shows that there is a significant difference in each of the statements presented in the lirkert scale to measure the level of the entrepreneurial skills between the trained smallholder women farmers and those who were not trained.

Table 8. Level of entrepreneurial skills of respondents

\begin{tabular}{|c|c|c|c|c|c|c|c|}
\hline \multirow[b]{2}{*}{ Entrepreneurial skills } & \multicolumn{2}{|c|}{$\begin{array}{l}\text { Trained } \\
\text { Women }\end{array}$} & \multirow{2}{*}{$\begin{array}{l}\text { Not } \\
\text { Women } \\
\text { Mean }\end{array}$} & \multirow{2}{*}{$\begin{array}{l}\text { trained } \\
\text { SD }\end{array}$} & \multicolumn{2}{|c|}{$\begin{array}{c}\text { Overall } \\
\text { sample }\end{array}$} & \multirow[t]{2}{*}{ t-value } \\
\hline & Mean & SD & & & Mean & SD & \\
\hline $\begin{array}{l}\text { Always apply new techniques to } \\
\text { generate more sales }\end{array}$ & 3.600 & 0.494 & 2.883 & 0.613 & 3.242 & 0.554 & $7.050 * * *$ \\
\hline $\begin{array}{l}\text { Take corrective action without } \\
\text { being told }\end{array}$ & 3.583 & 0.497 & 3.400 & 0.494 & 3.492 & 0.496 & $2.026^{* *}$ \\
\hline $\begin{array}{l}\text { Ability to genuinely connect, } \\
\text { understand and empathize with } \\
\text { your customers }\end{array}$ & 3.717 & 0.454 & 3.567 & 0.4997 & 3.412 & 0.477 & $1.720^{* *}$ \\
\hline $\begin{array}{l}\text { Ability to strategize for } \\
\text { achieving long- term goals }\end{array}$ & 3.400 & 0.494 & 2.600 & 0.494 & 3.00 & 0.494 & $8.869 * * *$ \\
\hline $\begin{array}{l}\text { Keep up to date records for } \\
\text { every } \\
\text { enterprise }\end{array}$ & 3.267 & 0.548 & 2.233 & 0.647 & 2.75 & 0.598 & $9.434 * * *$ \\
\hline $\begin{array}{l}\text { Able to communicate effectively } \\
\text { with everyone involved in the } \\
\text { smooth running of the business }\end{array}$ & 3.633 & 0.486 & 3.400 & 0.527 & 3.152 & 0.507 & $2.521 * * *$ \\
\hline $\begin{array}{l}\text { Can control the activities of the } \\
\text { business towards anticipated } \\
\text { goals }\end{array}$ & 3.583 & 0.497 & 3.333 & 0.475 & 3.458 & 0.486 & $2.815 * * *$ \\
\hline $\begin{array}{l}\text { Able to apply mitigation } \\
\text { strategies } \\
\text { to manage risks }\end{array}$ & 3.417 & 0.497 & 2.867 & 0.430 & 3.142 & 0.464 & $6.478 * * *$ \\
\hline $\begin{array}{l}\text { Able to coordinate the operations } \\
\text { of the enterprise }\end{array}$ & 3.767 & 0.426 & 3.467 & 0.503 & 3.617 & 0.465 & $3.523 * * *$ \\
\hline $\begin{array}{l}\text { Ability to manage your financial } \\
\text { resources and expenses }\end{array}$ & 3.333 & 0.475 & 2.917 & 0.381 & 3.125 & 0.428 & $5.295 * * *$ \\
\hline $\begin{array}{l}\text { Can draw up financial statements } \\
\text { without seeking any help }\end{array}$ & 3.033 & 0.317 & 1.950 & 0.649 & 2.492 & 0.483 & $11.617 * * *$ \\
\hline $\begin{array}{l}\text { Ability to organize resources } \\
\text { towards achieving the goal of the } \\
\text { business }\end{array}$ & 3.717 & 0.454 & 3.483 & 0.504 & 3.600 & 0.479 & $2.664 * * *$ \\
\hline Total average scores & 3.504 & 0.470 & 3.010 & 0.518 & 3.210 & 0.494 & \\
\hline
\end{tabular}


Where $* *, * * *=$ significance level of, $5 \%, 1 \%$, respectively

\section{Estimating the determinants of the level of Women Farmers' level of entrepreneurial spirit}

Results in Table 9 indicate that the overall model adjusted $\mathrm{R}^{2}$ value was 0.752 means that the dependent variable is explained by $75.2 \%$ of all independent variables. The results from the ANOVA table show that the regression model was significant at $1 \%$. The age of the respondents, level of education, major employment and the respondents' income from remittances have a positive and significant influence on the level of entrepreneurial spirit of the smallholder women farmers at 5\%,5\%,10\% and 10\%, respectively. Although a slight significant influence, a unit increases in age by 1 year result in a $0.6 \%$ increase in the level of entrepreneurial spirit. Sometimes age is linked to experience where a farmer develops survival strategies of minimizing risk and this creates a positive entrepreneurial spirit to carry on. In addition to experience, education also forms human capital important in agribusiness. Results presented in Table 9 further indicate that a unite increase in the number of years in school by 1 year results in 5.8\% increase in the level of entrepreneurial spirit. Education is important especially in acquisition of farm knowledge since most communication by extension officers and books is presented in English requiring one to read, interpret and implement the technologies.

Table 9. Relationship between socio-economic characteristics and level of entrepreneurial spirit

Coefficients Std. Error t-value Sig.

\begin{tabular}{|c|c|c|c|c|}
\hline (Constant) & 3.861 & 0.267 & 14.445 & 0.000 \\
\hline Age of respondent (years) & 0.006 & 0.003 & 2.042 & $0.044^{* *}$ \\
\hline Marital status of respondent ( $1=$ married, $0=$ otherwise $)$ & -0.003 & 0.025 & -0.131 & 0.896 \\
\hline Level of education of respondent (years in School) & 0.058 & 0.029 & 2.019 & $0.046^{* *}$ \\
\hline $\begin{array}{l}\text { Major employment of respondent }(1=\text { farming, } \\
0=\text { otherwise })\end{array}$ & 0.043 & 0.025 & 1.720 & $0.088^{*}$ \\
\hline Respondent's income (Emalangeni) & $-2.076 \mathrm{E}-006$ & 0.000 & -0.092 & 0.927 \\
\hline Respondent's income off-farming (Emalangeni) & $-3.547 \mathrm{E}-005$ & 0.000 & -1.240 & 0.217 \\
\hline Respondent's income from remittances Emalangeni) & 0.000 & 0.000 & 1.641 & $0.104^{*}$ \\
\hline Previous job of respondent ( $1=$ Formal, $0=$ Otherwise $)$ & -0.010 & 0.048 & -0.213 & 0.831 \\
\hline \multicolumn{5}{|l|}{ Adjusted $\mathrm{R}^{2}=0.752$} \\
\hline \multicolumn{5}{|l|}{$\mathrm{F}$ Value $=41.082$} \\
\hline$(\mathrm{p}=0.00<0.05)$ & & & & \\
\hline
\end{tabular}

Where $*, * *=$ significance level of, $10 \%, 5 \%$, respectively

The positive impact from the increasing age of respondents is probably caused by that the youth is not participating in agricultural activities because of rural urban migration (Kibirige, 2013). The youth find agriculture less attractive to them and so a majority of the active farmers are much older. This is because finding a job for much older people is difficult as they are regarded to as the group that is not active so they then opt for doing agriculture to 
earn a living for themselves and their families resulting in an increase in their level of entrepreneurial spirit. The results from this study match the results of a study that was conducted by (Remi, 2010) which states that age and the level of education has a significant effect on the performance of small-scale entrepreneurs on their small business. However a study conducted by Tamizharasi (2010) found that entrepreneurs above the age of 50 have a low level entrepreneurial spirit as compared to other age groups.

\section{Estimating the Determinants of women farmers' level of entrepreneurial skills}

Table 10 results indicate that the adjusted $\mathrm{R}^{2}$ value was 0.515 meaning that the dependent variable is explained by $51.5 \%$ of the total independent variables. The results from the ANOVA table show that the regression model was significant at $1 \%$. The results from the regression model show that the socio-economic characteristics of the smallholder women farmers indicate that marital status though negative and previous job of the respondents had a significant influence on the level of entrepreneurial skills at $5 \%$ level, while the total incomes earned and off-farm income had a positive and significant influence on the level entrepreneurial skill of smallholder women farmers at $1 \%$ and $10 \%$ level respectively. Thus being unmarried, access more income and previously worked in the formal sector increases the level of entrepreneurial skills of respondents.

Table 10. Relationship between socio-economic characteristics and level of entrepreneurial skills

\begin{tabular}{|c|c|c|c|c|}
\hline & Coefficients & & -value & Sig. \\
\hline (Constant) & 2.938 & 0.185 & 15.897 & 0.000 \\
\hline Age of respondent (years) & 2.634E-005 & 0.003 & 0.009 & 0.993 \\
\hline Marital status of respondent $(1=$ married, $0=$ otherwise $)$ & -0.093 & 0.045 & -2.055 & $0.042 * *$ \\
\hline Level of education of respondent (years in School) & 0.012 & 0.030 & 0.406 & 0.686 \\
\hline $\begin{array}{l}\text { Major employment of respondent }(1=\text { farming, } \\
0=\text { otherwise })\end{array}$ & -0.068 & 0.063 & -1.078 & 0.283 \\
\hline Respondent's income (Emalangeni) & 0.000 & 0.000 & 10.323 & $0.000 * * *$ \\
\hline Respondent's income off-farming (Emalangeni) & 4.953E-005 & 0.000 & 1.663 & $0.099 *$ \\
\hline Respondent's income from remittances Emalangeni) & $-4.847 \mathrm{E}-005$ & 0.000 & -0.726 & 0.470 \\
\hline $\begin{array}{l}\text { Previous job of respondent ( } 1=\text { Formal, } 0=\text { Otherwise }) \\
\text { Adjusted } \mathrm{R}^{2}=0.515\end{array}$ & 0.096 & 0.049 & 1.946 & $0.054^{*}$ \\
\hline $\mathrm{F}$ Value $=16.779(\mathrm{p}=0.00<0.05)$ & & & & \\
\hline
\end{tabular}

Where $*, * *, * * *=$ significance level of, $10 \%, 5 \%, 1 \%$, respectively

Marital status of the respondents has a negative impact probably because a large percentage of both the trained farmers and those who were not trained are married and married women are hardly able to make their own decision they have to consult from their husbands first and if the men are against their entrepreneurial ideas then their entrepreneurial skills will decrease.

\section{Challenges faced by smallholder women farmers}

The findings of presented in Table 11 showed that the entrepreneurial spirit and skills of the women smallholder farmers were constrained by the following challenges: lack of 


\section{Macrothink}

Journal of Agricultural Studies

ISSN 2166-0379

2020, Vol. 8, No. 2

information on agronomic practices, lack of capital, low rainfalls, lack of access to credit, lack of access to markets, poor soil fertility, lack of access to market information, lack of transport for produce, pests and diseases and theft.

Table 11. Challenges faced by smallholder women farmers

\begin{tabular}{lcc}
\hline Challenge & Frequency & Percentage \\
\hline Lack of information on agronomic practices & 74 & 62 \\
Lack of capital & 102 & 85 \\
Low rainfalls & 90 & 75 \\
Lack of access to credit & 115 & 96 \\
Lack of access to markets & 106 & 67 \\
Poor soil fertility & 80 & 73 \\
Lack of access to market information & 87 & 58 \\
Lack of transport for produce & 69 & 81 \\
Pests and diseases & 97 & 83 \\
Theft & 100 & 58 \\
\hline
\end{tabular}

\section{Conclusion}

The findings of this study show that socio-economic characteristics like age and the level of education do impact the level of entrepreneurial spirit and skills of women smallholder farmers positively. The performance of the smallholder farmers is constrained mostly by the lack of access to credit, lack of market access, lack of capital, the outbreak of pest and diseases and theft. The results also reveal that there is a significant difference in the level of entrepreneurial spirit and skills between trained smallholder women farmers and those who did not receive training, therefore, it can be concluded that business management training is an important tool to enhance the level of entrepreneurial spirit and skills of smallholder farmers for better performance in agricultural production.

\section{Recommendations}

In light of the findings of the study, the following recommendations were made by the researcher; 
$>$ Farmers should involve the young members of their families in the entrepreneurial activities so that they grow up well versed in this field and hence increasing the percentage of the youth that is participating in the agriculture sector.

$>$ The government, NGOs and CBOs, and the private sector providing farmer training services should go an extra mile of helping farmers access credit, markets and capital to boost their entrepreneurial spirit leading to increased productivity and profitability of their businesses.

$>$ More institutions should invest more in the business management training program of agricultural entrepreneurs since it proved to be an important tool to enhance entrepreneurial spirit and skills.

\section{References}

Agarwal, B. (2011). Food Crises and Gender Inequality. Retrieved on April 2019

Aghajani, M. A. (2012). Explanation of Relationships between Biographical Characteristics and Entrepreneurship Spirit of Students. Iranian Journal of Management Studies Vol.5, No.1, 17.

Agriculture, U. D. (2012). Women in Agriculture.

Aslam, S., Latif, M., \& Aslam, M. (2013). Problems Faced by Women Entrepreneurs and Their Impact on Working Efficiency of Women in Pakistan. Middle-East Journal of Scientific Research, 18(8), 1204-1215, 2013 ISSN 1990-9233, 1210-1213.

Burch, J. (2018). Basic concepts and characteristics of entrepreneurship. Berkeley: AZ Central.

Cheryl, D. (2011). The role of women in agriculture. Rome.

Collett, K., \& Chris, G. (2009). Training for rural development; Agricultural and enterprise skills for women smallholders. London: City\& Guilds Centre for Skills Development, 24-30 West Smithfield.

Cuervo, A., Ribeiro, D., \& Roig, S. (2017). Entrepreneurship: Concepts, Theory and Perspective. Introduction. Madrid.

Dhenak, M. S. (2017). Concepts of Entrepreneur, Entrepreneurship.

Dinis, A. M. (2011). Behaviours and entrepreneurial intention: Empirical findings about secondary students. J. Int. Entrep., 9, 20-38. https://doi.org/10.1007/s10843-010-0071-9

Fabamise, S. P. (2015). Problems Being Fcaed by Women Entrepreneurs in Rural Areas.

FANPARN. (n.d.). Strengthening the Capacity of Women Farmers to Influence Agricultural Policy Development in Southern Africa. Pretoria. 


\section{Macrothink}

Journal of Agricultural Studies

ISSN 2166-0379

2020, Vol. 8, No. 2

Gbadeyan, N. Y. (2017). Effects of Soci-economic Factors on Entrepreneurship Activities in Cape Coast, Ghana. Journal of Entrepreneurship and Business, E-ISSN: 2289-8298. https://doi.org/10.17687/JEB.05.01.04

Gwivaha, F. A. (2015). Factors that Impact Agricultural Extension Training Programs for Smallholder Women Farmers in Njombe District Tanzania. Iowa State University Capstones, Theses and Dissertations, 79.

Holden, R. (2019, May 11). Retrieved from http://www.robertholden.com.

Holienka, M., Holienkova, J., \& Gal, P. (2015). Entrepreneurial Characteristics Of Students In Different Fields Of Study: A View From Entrepreneurship Education Perspective. Acta Universitatis Agriculturae Et Silviculturae Mendelianae Brunensis, 63, 11. https://doi.org/10.11118/actaun201563061879

Kibirige, D. (2013). The impact of human dimensions on smallholder farming in the Eastern Cape of South Africa.

Kimmons, R. (2018). Basics concepts and characteristics of entrepreneurship. China: Chinese Literature Today.

Lee, N. (2016). Introduction to Entrepreneurship. Apex striving.

Llanto, G. (2010). Overcoming Obstacles to Agricultural Finance; Looking at Broader Issues. Asian Journal of Agriculture and Development, 4(3), 24-40.

Masuku, T. (2012). The empowerment of rural women and their role in poverty and hunger eradication, development and current challenges. New York.

Mucavele, S. (2013). The role of rural women in agriculture. Mozambique.

Mukasa, H., Nalmansi, E., Egeru, A., Ekwamu, R., Atim, P., \& Edimu, M. (2016). Promoting farmer entrepreneurship among smallholders in Uganda. Fifth RUFORUM Biennial Regional Conference (p. 11). Kampala: Egeru, Anthony.

Okello, Bell, Silvia Paruzzolo, Rekha Mehra, Adithi Shetty, and Ellen Weiss. n.d. "Agrodealerships in Western Kenya: How Promising for Agricultural Development and Women Farmers?" Washington, DC: International Center for Research on Women. Accessed at: https://www.icrw.org/wp-content/uploads/2016/10/Kenya-Agrodealers-FINAL.pdf

Qosja, E., \& Druga, E. (2015). Entrepreneurial spirit and factors affecting it: A case study based on the students of the European University of Tirana. 688. https://doi.org/10.24289/ijsser.279146

Remi, A. A. I. (2010). Impact of Socio-economic Factors on the Performance of Small-scale Enterprises in Osun State, Nigeria. International Business Research, 8.

Riley, J. (2018, October 10). Tutor2u. Retrieved from

www.tutor2u.net/business/reference/introduction-to-training-employees. 


\section{Macrothink}

Journal of Agricultural Studies

ISSN 2166-0379 2020, Vol. 8, No. 2

Smith, J. (2013). How to keep your entrepreneurial spirit alive as the company you work for grows. Forbes Staff.

Standard Bank (2018).Financial Data

Tamizharasi, D. N. (2010). An Empirical Study of Demographic Variables on Entrepreneurial attitudes. International Journal of Economics, 1(2), 6.

https://doi.org/10.7763/IJTEF.2010.V1.40

Tarmizi, M. H., Rozana, N., \& Rahim, H. (2016). Women Entrepreneurs in the Agriculture Sector: Issues and challenges. Economic and Technology Management Review, 11a, 9.

VAC (2019). Integration Food Security Phase Classification acute food insecurity analysis. July 2019, Mbabane, Swaziland.

Vettas, N. (2006). Market Control and Competition Issues Along the Commodity Value Chain. In Governance, coordination and distribution along commodity value chains.

Wiafe T, Y. L. (2016). Farm Business Management Skills a Missing link for Smallholder Farmers: a case of Malingunde, Malawi. European Journal of Business and Innovation Research.

\section{Copyright Disclaimer}

Copyright for this article is retained by the author(s), with first publication rights granted to the journal.

This is an open-access article distributed under the terms and conditions of the Creative Commons Attribution license (http://creativecommons.org/licenses/by/4.0/). 